\title{
Fishing Quota and International Obligation: Why Has Indonesia been Indicated as a Non-Compliant State
}

\author{
Rachma Indriyani ${ }^{1}$, Asmar Binti Abdul Rahim², Ruzita Binti Azmi ${ }^{3}$ \\ ${ }^{1}$ School of Law, COLGIS, Universiti Utara Malaysia.E-mail: rachma.indriey@gmail.com \\ 2 School of Law, COLGIS, Universiti Utara Malaysia.E-mail: asmar@uum.edu.my \\ ${ }^{3}$ School of Law, COLGIS, Universiti Utara Malaysia. E-mail: zita@uum.edu.my
}

\begin{abstract}
Indonesia committed to conserving the tuna resources by participating in some RFMOs. From all regional organizations where Indonesia has been joined, the CCSBT is the unique one, due to it governs a single tuna species, which is called Southern Bluefin Tuna. This kind of tuna is essential for Indonesia because it is the world's most expensive tuna and SBT migrates through Indonesian fisheries management zones and goes even further within the territorial waters, where the SBT spawning area is located. This natural characteristic distinguishes Indonesia from other Parties to CCSBT. Nevertheless, the Country has been dealing with its obligation to comply with national quota allocation. For some fishing season periods, the CCSBT indicated Indonesia as a non-compliant. By applying the qualitative approach, this study considers how Indonesia's non-compliance has been addressed in fishing for shared fish stocks. The data collection was conducted through semi-structured interviews and legal analysis of law and policy instruments. This method leads the elaboration to reveal domestic factors affecting noncompliance by Indonesia. This study argues, the fisheries legislation should consider the provision concerning fishing for resources under quota system, hence, it will provide sufficient legal base to take enforcement measures towards non-compliance with fishing quota.
\end{abstract}

Keywords: Compliance; Fishing Quota; Shared Fish Stocks; Quota Allocation

\section{Introduction}

The non-compliance of international law costs two primary concerns. First, once the international legal obligation has been violated, that breach can shrink the authority of the obligation itself. Despite the lack of concern of the breaching State, however, it will be a concern to others or non-breaching States that rely upon the obligation breached, regardless of whether they do not immediately harm the particular breach at issue. Further, non-compliance action can obstruct the establishment of the international rule of law, as well as the maintenance of a habit of obedience. The habits of observing and accepting the law will make international order in stability. Therefore, any breach of an international obligation can weaken the authority of the rule breached and also the integrity of the international legal system. Considering that the stability of the international system as a whole is influenced by compliance action, consequently, all States, despite States which are not joining as party to the international agreement, might have an interest in compliance. ${ }^{1}$

\footnotetext{
${ }^{1}$ Cogan, J. K. (2006). Noncompliance and the international rule of law. Yale J. Int'l L., 31, 189.
} 
Compliance's member is used as a criterion in determining fishing quota for international shared-fish stock allocated by Regional Fisheries Management Organization (RFMO). When over-quota has been identified, the corrective measure will be considered by RFMO towards the non-compliant member. The Commission for the Conservation of Southern Bluefin Tuna (CCSBT) is one of the fishery organizations that apply quota reductions with regards to over-quota. ${ }^{2}$ In the Corrective Actions Policy, when the catch is more than the member's annual quota, the member is required to do quota payback. Otherwise, there will be two situations enforced as follows:

Member shall not apply the carry-forward procedures provided in CCSBT's Resolution on Limited Carry-forward of Unfished Annual Total Available Catch of Southern Bluefin Tuna (SBT) until those catches have been paid back unless otherwise agreed by the Extended Commission, and the Member is not eligible for an increase in its effective catch limit until the excess catch has been paid back unless otherwise agreed by the Extended Commission.

With high repetition on exceeding the national quota, the Country's fishing vessel could possibly be considered as non-compliance if there is no actions taken by the government to improve the control and monitoring towards vessels flying its flag. ${ }^{3}$ When the Country is indicated as non-compliant with fishing quota, it will impact to the Country's reputation in international fisheries, moreover, there will be possibility that the Country will be imposed for a reduction in its quota allocation. Therefore, noncompliance is one of the most significant threats facing good fisheries governance and conservation attempts today. The enforcement of compliance with management measures of RFMOs is pivotal to ensuring that these organizations fulfil the role envisaged for them under international law. ${ }^{4}$

Being experienced with over-catch of SBT quota for some fishing season, it can be assumed that Indonesia is seriously undermining the combined efforts of other CCSBT Member governments to rebuild stocks of SBT which has been in a perilous situation. Since ratified and participated in international agreements, Indonesia is subject to its commitment to adopting international provisions into national legislation. While tuna RFMOs can be seen as suitable one to manage resources, in fact international frameworks are likely lack of power on its compulsory jurisdiction when it comes to transboundary fisheries. The legal consequences of a violation as well as the possible redress mechanisms need to be clearly settled due to the migratory nature of SBT. ${ }^{5}$

Martin Tsamenyi and Quentin Hanich added that a major gap in international framework was the lack of compatibility between the regimes of the high seas and Exclusive Economic Zones. No international legal instruments address fisheries

\footnotetext{
2 Cox, A. (2009). Quota allocation in international fisheries. OECD Food, Agric. Fish. Pap., no. 22, pp. 161.

3 Miller, D. D., \& Sumaila, U. R. (2014). Flag use behavior and IUU activity within the international fishing fleet: Refining definitions and identifying areas of concern. Marine Policy, 44, 210.

4 Clark, E. A. (2011). Compliance enforcement in regional fisheries management organizations to which Australia is a party (Doctoral dissertation, University of Tasmania). 38.

5 Southern Bluefin Tuna-Species Impact Statement. (2009). available online from https://www.dpi.nsw.gov.au/data/assets/pdf file/0004/508018/southern bluefin tuna sis part 1.pdf
} 
jurisdiction in maritime zones under the sovereignty of coastal States. There would be a risk to the effective action across the range of the stock if large areas under coastal State sovereignty are excluded from any measurement adopted by RFMOs. Hence, the fisheries governance framework is almost entirely at the discretion of the coastal State. ${ }^{6}$

Being such precious fish, SBT has been indicated as critically endangered. Over-fishing and catching SBT exceeds than allocated quota are two crucial challenges in achieving the sustainable objective. ${ }^{7}$ Moreover, in the field of fisheries conservation, emphasis has been placed by quantitative analyses in the context of how to do stock enhancement. ${ }^{8}$ This type of analyses has not captured the wider impacts of the conservation. Science is indeed the basic to make decisions about what to do with our natural resources, however it should also be based on other aspects such as politic, economic, and cultural considerations. While questioning the way to integrate those diverse perspectives to create policy outcomes, a qualitative social approach is an interconnected way of different types of knowledge and comprehend them in a more effective marine resources governance. ${ }^{9}$

This study argues that without adequate law enforcement, the quota allocation system does not contribute to SBT sustainability. Furthermore, international law instruments for conservation measures will never be worked in driving any State to comply unless the national laws of each member States support to do so. This study critically identifies non-compliance issues in fishing for international shared-fish stock which Indonesia has been dealing with and examines to what extend domestic factors affecting Indonesia's compliance with international provisions. In this light, this study contributes to provoke the needs to include the legal provision concerning fisheries under quota management into national legislation.

\section{Method}

The study applies a qualitative approach and uses content analysis to construct the main problem's argument. A qualitative method of this study can help to take an essence of social legal evaluation of marine resource use and conservation. As Levontin"10 described that "connected knowledge that qualitative social science can produce, it is possible to understand more about what the likely consequences of

\footnotetext{
${ }^{6}$ Tsamenyi, M., \& Hanich, Q. (2012). Fisheries jurisdiction under the Law of the Sea Convention: rights and obligations in maritime zones under the sovereignty of Coastal States. The International Journal of Marine and Coastal Law, 27(4),792.

${ }^{7}$ Mclntyre, P. B., Reidy Liermann, C., Childress, E., Hamann, E. J., Hogan, J. D., Januchowski-Hartley, S. R., ... \& Pracheil, B. M. (2016). Conservation of migratory fishes in freshwater ecosystems (pp. 324-360). Cambridge University Press: Cambridge.

8 Bell, J. D., Leber, K. M., Blankenship, H. L., Loneragan, N. R., \& Masuda, R. (2008). A new era for restocking, stock enhancement and sea ranching of coastal fisheries resources. Reviews in fisheries science, 16(1-3), 1-9.

9 Jentoft, S. (2006). Beyond fisheries management: The Phronetic dimension. Marine Policy, 30(6), 671-680.

10 Levontin, P., Kulmala, S., Haapasaari, P., \& Kuikka, S. (2011). Integration of biological, economic, and sociological knowledge by Bayesian belief networks: the interdisciplinary evaluation of potential management plans for Baltic salmon. ICES Journal of Marine Science, 68(3), 632-638.
} 
policies before they are implemented".

The data collection was carried out in two ways. First, semi-structured interviews and analyzing relevant law instruments. Semi-structured interviews were conducted with some key informants who doing responsibility in managing the fishing quota in Indonesia. Several respondents have never been specific in qualitative research. ${ }^{11}$ However, the respondents were selected following their significant responsibility. The main interview was conducted through confirmation to some figures from the Ministry of Marine Affairs and Fisheries, having their role as Indonesia representative who participated in the CCSBT annual meeting. An interview was held with a Tuna Association member to get more knowledge concerning the real problem and practical matter. In addition, the discussion was carried with the compliance manager of CCSBT to obtain confirmation regarding compliance policy and particular action plans during the pandemics. Second, relevant data were obtained by studying the law instrument and regulations and documentary materials, including the official report by Regional Fisheries Management Organization, particularly the CCSBT.

\section{The Non-Compliance Issue}

The purpose of fishing quota regulation is a limitation of fishery exploitation, especially for international or shared fish stocks. ${ }^{12}$ To get access to international fisheries, it is mandatory between coastal States and flag States who fish in the region, as mentioned in Articles 63(2) and 64 of the United Nations Convention on the Law of the Sea (UNCLOS), to cooperate through RFMOs to ensure the conservation goal of fish stocks. Further, the cooperation should encourage the optimum utilization of the stocks, either within or beyond the Exclusive Economic Zones of a State.

The conservation and management measures provided in CCSBT provision indicates that members will report any fishing violation and take measures to ensure their flagged vessels meet the compliance. There are three sources which member States could be considered as non-compliance: ${ }^{13}$

"(i) administrative failings, including not fully implementing effective systems and processes to support obligations; (ii) failure by Members to take action against non-compliance by fishers, farmers, processors, exporters or importers within their jurisdiction, and (iii) deliberate actions by Members to avoid meeting obligations."

The first element of Annex I of Minimum Performance Requirements to meet CCSBT Obligations sets out obligations relating to compliance with national quota allocations. Member State shall ensure that its total attributable SBT catch for a quota year shall not exceed its TAC.

\footnotetext{
${ }^{11}$ Al amaren, E. M., M. Z. bin M. Nor, and C. T. B. M. Ismail. (2020). Risks and Remedy in Islamic and Conventional Letter of Credit: Jordanian Practices," Int. J. Islam. Econ., vol. 2, no. 01, 54.

12 Hatcher, A., \& Pascoe, S. (2006). Non-compliance and fisheries policy formulation. In Developments in aquaculture and fisheries science (Vol. 36, pp. 355-373). Elsevier.

13 CCSBT. Corrective Actions Policy, Compliance Policy Guideline 3. (2018). updated at the TwentyFifth Annual Meeting
} 
SBT quota in Indonesia is allocated for association namely Indonesia Tuna Association (ASTUIN) and Indonesia Tuna Long-line Association (ATLI). Each association will get 50\% catch allocation of Indonesia annual catch quota. In 2010, the Integrated Fishing Fisheries Association (ASPERTADU) was formed in which the association only gets quota allocations from associations whose catch is less than the specified quota. ${ }^{14}$ The quota distribution refers to the Decision of Director General of Capture Fishery No. 75/KEPDJPT/2014 regarding the Technical Guidelines for the Distributions of Southern Bluefin Tuna Quota Allocations.

\subsection{Over-catch}

According to the Indonesia Annual Report to the Compliance Committee and the Extended Commission CCSBT, Indonesia have encountered over-catch problem on SBT quota ${ }^{15}$ since 2011 until 2014. In the latest progress, the over-catch has been occurred again in 2019-2020 fishing season as shown in the Table 1.

Table 1. Indonesia's Quota Allocation and Over-Catch (2011-2019)

\begin{tabular}{|c|c|c|c|}
\hline $\begin{array}{l}\text { Fishing } \\
\text { Season }\end{array}$ & $\begin{array}{c}\text { National SBT } \\
\text { Allocation } \\
\text { (ton) }\end{array}$ & $\begin{array}{l}\text { Total SBT Catch } \\
\text { Counted against the } \\
\text { National Allocation } \\
\text { (ton) }\end{array}$ & Causes for over-catch \\
\hline 2011 & 651 & 843 & $\begin{array}{l}\text { due to capacity building and a wide range of } \\
\text { vessels size in the artisanal fisheries }\end{array}$ \\
\hline 2012 & 685 & 910 & $\begin{array}{l}\text { the existence of artisanal or small-scale } \\
\text { fisheries }\end{array}$ \\
\hline 2013 & 709 & 1383 & $\begin{array}{l}\text { There is no SBT quota for vessels artisanal } \\
\text { vessels. The reason is that the national quota is } \\
\text { considered too small compared to the number } \\
\text { of vessels involved. Meanwhile, there is a need } \\
\text { to accommodate their right and interest }\end{array}$ \\
\hline 2014 & 750 & 1063 & $\begin{array}{l}\text { (a) SBT is considered as by-catch or un-intended } \\
\text { catch to artisanal vessels, (b) a huge number of } \\
\text { fleets with a wide- range of size involved, (c) a } \\
\text { lot of people depend on their life on tuna } \\
\text { fisheries, including SBT }\end{array}$ \\
\hline 2019 & 1024 & 1206 & $\begin{array}{l}\text { the COVID- } 19 \text { pandemic that had a great impact } \\
\text { on the economy, the fisheries sector in } \\
\text { Indonesia changes its strategy to operate } \\
\text { almost their entire fleet and increasing } \\
\text { operation days. }\end{array}$ \\
\hline
\end{tabular}

Source: Annual Report CCSBT, 2011-2020 (edited).

14 Interview with the Ministry of Fisheries and Marine Affairs of Indonesia in Jakarta on 3 February 2020

15 SBT quota is allocated for association namely Indonesia Tuna Association (ASTUIN) and Indonesia Tuna Long-line Association (ATLI). Each association will get $50 \%$ catch allocation of Indonesia annual catch quota. 
The background of Indonesia exceeded SBT quota was revealed in the Report of the Twentieth Annual Meeting of the Commission which Indonesia have been facing the difficulties in handling SBT catches due to the involvement of hundreds of small-scale tuna long-line vessels that SBT is not their main target. The explanation delivered by Indonesia representative as stated as follows: ${ }^{16}$

"But after implementing the quota approach within 5 (five) years, we have had some difficulties controlling the annual catch limit based on the current reserved quota, due to the existence of artisanal tuna long-liner or small-scale fisheries, that are mainly fishing within Indonesia fisheries management zone. We could not prevent them from catching SBT, since SBT is caught as unexpected by-catch. We also could not blame them or fine them from catching SBT, since they are not intending to catch the fish, but other tunas as their main livelihood. Moreover, they have been involving in this artisanal tuna longline fisheries for some decades."

The small-scale tuna fleets involvement was also elaborated in the 2017 Annual Report to the Ecologically Related Species Working Group. Even though, it was then explained that SBT caught as unintended by-catch for this fleets, thus the allocation of national quota did not count to the small-scale tuna fleets. From this point, instead of further clarification on whether authorized tuna fleets that have been registered and received quota have always been met their quota portion, it seems the assumption on the SBT over quota is described as the quota overused by small scale tuna fleets catch SBT.

As Indonesia authority recognized that the small-scale fishermen involved in CCSBT fishery was catching SBT unintentionally and for daily living needs, it can be assumed those small-scale fishermen, as individual, do not have historical catch for SBT stocks. Since there is no national law regulation as an umbrella to the condition for small scale fishermen, therefore, the fishing vessel and the SBT catch of small-scale fishermen can be potentially classified as "illegal and unreported fishing".

\subsection{Unreported Catch}

In order to legally fish for SBT stocks, a fishing vessel must be joined association to gain certain SBT quota and must be registered in CCSBT record as a vessel authorized to fish. This is clearly mention in Resolution on a CCSBT Record of Vessels Authorized to Fish for SBT paragraph 9: "Fishing Vessels not entered into the Record are deemed not to be authorized to fish for, retain on board, transship or land SBT regardless of their size".

In pursuant to Resolution on Establishing a List of Vessels Presumed to have Carried Out Illegal, Unreported and Unregulated Fishing Activities for Southern Bluefin Tuna, Article 3 mentioned some categories of evidence that a vessel shall be included in IUU fishing activities:

a. Harvested SBT and were not authorized by a member or CNM to fish for SBT, or;

b. Did not record and/or report their SBT catches or catch-related data in accordance with CCSBT reporting requirements, or made false reports, or;

\footnotetext{
${ }^{16}$ Commission for the Conservation of Southern Bluefin Tuna. (2013). Report of the Twentieth Annual Meeting of the Commission.
} 
In the context of small-scale tuna fleets catching SBT as non target species, it is essential to examine the small-scale fishermen position. First, only individual or company joined tuna association that will gain quota to catch SBT. Further, the fishing vessel must be registered in the CCSBT record to be authorized to catch SBT. Basically, small scale fishermen catch fish for daily living needs. In time they have caught SBT, it may count as non-target species (by-catch). Moreover, if refer to by-catch policy, Indonesia have issued some relevant policies to protect certain fish species. However, none of the list covering tuna or specifically SBT as by-catch. Meaning that every SBT catch from small scale fishermen can be assumed illegal fishing as they do not have authorization to do so, but the legal basis seems inadequate to trap their catches as by-catch itself.

Second, the law enforcement provision towards violation conducted by small scale fishermen is provided in the Fisheries Act No. 31 of 2004. According to Article 12, it is stated that "Every person is prohibited from committing an act that causes pollution and/or damage to fish resources and/or the environment in the Indonesian fisheries management area". The consequences of any breach to this provision conducted by small scale fishermen are stated in Article 100B of the Fisheries Act Amendment No.45 of 2009 that the action is considered as criminal act that is punishable by a maximum imprisonment of one year or a fine.

In addition, Article 7(2) of Fisheries Act No 45 of 2009 has underlined that "Every person conducting business and/or fishery management activities must comply with the provisions concerning type, number, and size of fishing gear; fishing area, route and time or season to catch; the operating procedure standard; and fishing boat monitoring system. Furthermore, it has added in Article 7(3) that the small-scale fishermen are excluded from the obligation to comply with "the fishing boat monitoring system" provision. While in contrast, Article $100 \mathrm{C}$ emphasized the fine punishment towards any small-scale fisherman committing act against the obligation in Article 7(2).

The law enforcement towards small scale fishermen shall be possibly groundless in practical due to an inharmonious between Article 7(3) and 100C. By disregarding small scale fishing activities into monitoring requirements, how can the government expect such activities to be considered non-compliance. As consequences, catching SBT by small scale fishermen seems likely untouchable by law and regulation since there is gap still remains regarding by-catch policy and the position of small-scale fisheries within regulation.

In addition, the issue of SBT caught by small-scale fisherman could potentially lead to illegal and unreported catch. The catch is illegal due to small-scale fishermen, principally, do not have authorization to do so. Indication for unreported catch is because there is no obligation for small-scale fishers to make catch report to the authority. ${ }^{17}$ Unclear reporting regime could lead to data uncertainties. This should be a concern especially because SBT is managed under international fisheries

17 In pursuant to CCSBT Resolution on Establishing a List of Vessels Presumed to have Carried Out Illegal, Unreported and Unregulated Fishing Activities for Southern Bluefin Tuna, Article 3 mentioned some categories of evidence that a vessel shall be included in IUU fishing activities. 


\subsection{Tagging Obligation}

Validation of the data collection and monitoring the SBT catches should refer to the Catch Documentation Scheme (CDS) procedure before port entry. This is obligation to all members and cooperating non-members to record all SBT movement through CDS procedure. Tagging is one of the critical elements of the CDS report as outlined in the Resolution on the Implementation of a CCSBT Catch Documentation Scheme.

In respect of fisheries data collection in particular SBT fishing, Indonesia have had experience with large inaccuracies and non-compliance. The discrepancy of Indonesian catches of SBT between the import statistics and the monitoring program results appeared significantly. Based on the data collected, it became apparent that the estimates of SBT catches by the Indonesian long-line fleet that were exported to Japan were shown to be greater than the catches reflected in the Japanese import statistics. ${ }^{18}$ Moreover, it was revealed from the 2019 report of Compliance with CCSBT Management Measures, Indonesia has not been tagging all SBT catches at the time kill:

"At least 606 SBT caught by Indonesia were not tagged at the time of kill, and in some cases could not have been tagged for up to 5 to 7 months after the time of kill".

From these fishery data accuracy issue as outlined earlier; it can be seen the SBT catches validation as the last defense before the fish attached to supply chain in the land is not transparent. Verification process towards the information collected will make the data become more accurate. Therefore, enumerators must be placed in every landing site. However, insufficient number of enumerators and many data entry operators that lack of technical competence and the archipelagic geography of Indonesian will probably make the fisheries data collection process costly. Consequently, the fisheries data did not really present the actual condition. ${ }^{19}$

Lack of enforcement actions towards SBT quota distribution will also impact data inaccuracy because of unreported fishing practices. The CCSBT report of compliance in 2019 mentioned the tagging issues to all SBT catches, ${ }^{20}$ showing that the tuna associations were unable to control the number of tags circulated due to members not reporting the tag use. ${ }^{21}$ Lack of monitoring by associations resulted inaccuracy between the government and the tuna association.

18 Polacheck, T. (2012). Assessment of IUU fishing for southern bluefin tuna. Marine Policy, 36(5), 1150-1165.

19 Khan, A. M., Mill, A. C., Gray, T. S., Jiang, M., Arief, H., Brown, A., ... \& Polunin, N. V. (2020). Reliability of the data on tuna catches obtained from the dockside in Indonesia: A study of stakeholders' perceptions. Marine Policy, 122, 104-242.

20 Commission for the Conservation of Southern Bluefin Tuna. (2019). Report of the Fourteenth Meeting of the Compliance Committee.

21 Novia Tri Rahmawati. (2014). Pengelolaan Kuota Penangkapan Tuna Sirip Biru Selatan di Indonesia. Institut Pertanian Bogor. 50. 


\section{Legal Factors Affecting Compliance with Quota}

There are two approaches in understanding the theory of compliance, namely the instrumental approach and normative approach. These two approaches can be considered to explain why States adopt and implement international laws. According to the instrumental approach, State's compliance is determined by self-interest with having expectation that the potential gain will be higher than the costs of noncompliance, regardless the sanctions due to such violation. In respect of high seas fisheries, the inherent weakness of this regime can lead certain individuals to calculate the cost or benefit analysis that there is more to be gained from fishing beyond national area. The absence of the threat of severe and effective sanctions, many individuals to avoid compliance behavior.

Meanwhile, the normative approach argues that State's nationals will comply if the laws are met with fair consideration, appropriate or legitimate. The legitimacy of international fisheries law was controversial in the late 1970s when the coastal states desired to regulate fisheries resources. That was the time when the introduction of EEZs concept emerged thus it made the coastal States gained $90 \%$ of the world's commercial fisheries jurisdiction. However, for those States denied this justification, the EEZ concept was seen as biased and unjust to the freedom to fish. In this approach, the personal perceptions of the fishers of States will influence they compliant behavior with international law. From these two approaches, it can be seen that compliance with the rules and international obligations in international fisheries is influenced by political will and strong commitment of States to employ the effective monitoring and enforcement of their vessels participating in international fisheries. ${ }^{22}$

\subsection{The Lacuna in Law towards the Engagement of Small-Scale Fishermen in SBT Fishing}

In respect of Indonesia's non-compliance on its total allowable catch of SBT has been considered due to the small-scale fishermen caught SBT unintentionally. In this particular context, CCSBT has issued regulation on Attributable SBT Catch in which the participation of small-scale fishermen or artisanal fishing in SBT fisheries should be included in mortality counts against national quota of a member State. Failed to include the SBT catch resulted from fishing activities, the member is indicated as noncompliance.

The CCSBT rules also concern with authorization towards fishing vessel to catch SBT. This is clearly mention in Resolution on a CCSBT Record of Vessels Authorized to Fish for SBT paragraph 9: "Fishing Vessels not entered into the Record are deemed not to be authorized to fish for, retain on board, transship or land SBT regardless of their size". That is to say, member States are expected to adopt into their national law regarding any subject matter from fishing activities within its jurisdiction that will contribute to the total SBT mortality and criteria to authorize the right to fish.

\footnotetext{
22 Elise Anne Clark. (2011). "Compliance enforcement in regional fisheries management organizations to which Australia is a party." PhD diss., University of Tasmania, 38.
} 
First and foremost, this study assumed that it is essential to examine the Indonesian law concerning the small-scale fishermen position. According to Indonesia national regulation there are two criteria to determine the right to fish for SBT. First, only individual or company joined tuna association that will gain quota to catch SBT. Further, the fishing vessel must be registered in the CCSBT record to be authorized to catch SBT. It means that every SBT catch from small-scale fishermen who do not join the tuna association and the vessel is not registered, then it can be assumed as illegal catch because they do not have authorization to do so.

Second, regarding mortality counts against SBT quota allocation, this study revealed how Indonesian law treats the SBT caught unintentionally by small-scale fishermen. The elaboration in Table 2 below demonstrates that the small-scale fishermen are excluded from monitoring system and reporting regime in the Fisheries Act. Therefore, the total SBT catch from the small-scale fishery is poorly known.

As shown in the Table 2, it seems none of national law provisions can apply such noncompliant labelling to small-scale fishermen as the law and regulations have granted the privilege to do so.

Table 2. The Regulatory Gaps on Small-Scale Fishers' Compliance

\begin{tabular}{|c|c|c|}
\hline Criteria & Law Provisions & Potentially non-compliance \\
\hline $\begin{array}{l}\text { Licensing or } \\
\text { fishing permit }\end{array}$ & $\begin{array}{l}\text { According to Fisheries Act } 2009 \text {, small } \\
\text { fishers are free from fishing license and } \\
\text { fish carrier license. } \\
\text { Similar provision is provided by the Law } \\
\text { No. } 23 \text { of } 2014 \text { concerning Regional } \\
\text { Government. }\end{array}$ & $\begin{array}{l}\text { There will be possibility for } \\
\text { unregulated fishing practices, illegal } \\
\text { transshipment at-sea, and the use of } \\
\text { destructive fishing gear }\end{array}$ \\
\hline Fishing area & $\begin{array}{l}\text { Fisheries Act } 2004 \text { has justified small } \\
\text { fishers free to fish in the whole Fisheries } \\
\text { Management Area (FMA) in Indonesia } \\
\text { water. }\end{array}$ & $\begin{array}{l}\text { The free access to whole area of FMA } \\
\text { will lead to nomadic fishing location. } \\
\text { The small fishers can land their catch } \\
\text { at nearby fishing port or the coast, } \\
\text { thus there might be possibility for } \\
\text { unreported fish. }\end{array}$ \\
\hline Reporting Catch & $\begin{array}{l}\text { Small fishers are exempted from } \\
\text { obligation to install VMS and reporting } \\
\text { requirement. }\end{array}$ & $\begin{array}{l}\text { Out of monitoring and the fish catch } \\
\text { data is uncertain or unreliable, there } \\
\text { will be potential unreported catch. }\end{array}$ \\
\hline
\end{tabular}

Source: primary source (edited)

By disregarding small-scale fishing activities into monitoring requirement, the legal basis seem inadequate to treat their SBT catches as illegal and unreported. As consequences, catching SBT by small-scale fishermen, whether intentionally or not, seems likely untouchable by law and regulations since there is a gap still remains regarding the absence of law towards the unclear position of small-scale fisheries in SBT fishing.

Considering the SBT's over-catch has happened frequently, SBT might have gradually changed from by-catch to main target. In order to determine the authorization or the right to fish, this thesis strongly recommends the need to create a legal framework that 
covers small-scale fishermen who caught SBT and how their catch should be legally treated

\subsection{The Extraterritorial Enforcement does not Reflect in Indonesian Law}

The equality in actions between areas within national jurisdiction and the high seas are important in order to achieve the international conservation and management measures. Recognizing that all States have the right for their nationals to access fish stocks on the high seas, in the same time, the cooperation among States for high seas conservation is necessary, then the international law must be a universal legal base for all States to adopt to ensure they conduct the effective flag State's responsibility on the high seas area.

The Food and Agriculture Organization (FAO) issued an agreement with respect to duties and responsibilities of the Flag States on the high seas, namely "Agreement to Promote Compliance with International Conservation and Management Measures by Fishing Vessels on the High Seas". The agreement mainly places concerns on the vessel engages in fishing activities in the high seas and underlines the following obligations: maintaining a record of authorized vessels; requiring the information on catch and fishing operation; the exchange of relevant information with FAO and other international agencies; ensuring all fishing vessels fly its flag do not engage in activities that will undermine the international of conservation and management measures.

This agreement gives legitimacy to FAO to serve as a clearinghouse for vessels fishing on the high seas. FAO developed the High Seas Vessels Authorization Record (HSVAR), which provides all States with the information regarding the record and authorization status of the vessels that have authorized by State Parties to fish in the high seas, also reveal information about infringements conducted by the respected vessels. By doing so, the information provided will influence the flag States, also Port States, to take responsible decisions. In addition, FAO only grants access to the database to the Parties that have fulfilled the information requirements. Nevertheless, the information exchange among States provided by this agreement will be effective depends upon how much the agreement's coverage which Parties have did ratification.

Until recently, Indonesia is not a Party of this compliance agreement. From all of CCSBT's member States, only Australia and New Zealand have ratified the agreement. By being State parties who ratified the agreement, both Australia and New Zealand have adopted compliance provisions in their fisheries law that enable the two countries to do enforcement towards national fishing vessels and foreign fishing vessels participating in SBT fishing in the area beyond national jurisdiction.

The essence of Indonesia to ratify the compliance agreement is to strengthen the commitment in ensuring the sustainable fishing not only within national jurisdiction. By doing so, this international agreement will be beneficial for the improvement of Indonesia national law on high seas fisheries, including highly migratory fish. There are two provisions of the compliance agreement which can be a legal base for national fisheries law improvement. First, the provision regarding small-scale fishing vessel that cannot be excluded from the effectiveness of international conservation and 
management measures. Paragraph 1 (b) of Article III of the compliance agreement is explained the respected purpose:

"In the event that a Party has granted an exemption for fishing vessels of less than 24 meter in length entitled to fly its flag from the application of other provisions of this Agreement, such Party shall nevertheless take effective measures in respect of any such fishing vessel that undermines the effectiveness of international conservation and management measures. These measures shall be such as to ensure that the fishing vessel ceases to engage in activities that undermine the effectiveness of the international conservation and management measures."

The second provision is about the obligation to take enforcement measures and sanctions towards the national fishing vessels acted in contravention of the purpose of international conservation. This provision will push Indonesia to formulate in national legislation concerning types of offences in high seas fisheries, as mentioned in paragraph 8 of Article III as follows:

"Each Party shall take enforcement measures in respect of fishing vessels entitled to fly its flag which act in contravention of the provisions of this Agreement, including, where appropriate, making the contravention of such provisions an offence under national legislation. Sanctions applicable in respect of such contraventions shall be of sufficient gravity as to be effective in securing compliance with the requirements of this Agreement and to deprive offenders of the benefits accruing from their illegal activities. Such sanctions shall, for serious offences, include refusal, suspension or withdrawal of the authorization to fish on the high seas".

\subsection{There is No Effective Sanction Measures towards Non-Compliance with Quota}

The main legal instrument to support enforcement measures in Indonesia's SBT fishery is Law No. 45 of 2009 on the Amendment of Fisheries Act 2004. There are three important elements for enforcement measures of these Fisheries Acts, namely license permit for fishing; fisheries monitoring vessel; and Fisheries Court. None of these provisions are specifically pointed to SBT fishing. The only national policy that includes SBT is National Tuna, Skipjack Tuna, and Neritic Tuna Management Plan. However, this policy document mainly outlines the management aspect, fish stock production and recovery.

Indonesia needs to provide secondary regulations concerning enforcement that incorporated the main legal instrument. As SBT management is under international regulation, each minimum requirement of enforcement governed by CCSBT guidelines should reflect national law and regulations. Referring to the main problem on overcatch that Indonesia still facing until now, the adopted enforcement approach should be adjusted with national situation and capacity.

While Indonesia's quota handled by tuna associations, the legitimacy to monitor compliance is different to each other. From interview conducted with authorities from the Ministry of Marine Affairs and Fisheries, it is known the quota allocation and 
monitoring system are completely dependent on the discretion by the tuna associations themselves. Nevertheless, it is quite difficult to access the relevant standard or guidelines provided by the tuna association or at least, how CCSBT's regulations have been adopted to ensure their members' compliance.

It is important to analyze whether the Indonesian Government has implemented such effective action against non-compliant vessels that have contributed to the over-quota issue. By reviewing the national law and supporting regulations, the result showed that the Government has given legitimation to tuna associations in managing and monitoring the quota used by the fishermen who are their association's members. Thus, the practical matter of quota distribution itself is completely under the management of tuna associations. In order to track the non-compliance, how the association conducts monitoring and sanctioning system towards all registered fishing vessels are essential. Apparently, the internal policy of the tuna associations is not easy to publicly accessible.

Considering the main objective of CCSBT is for the conservation of SBT resources, any member States are expected to enforce the compliance in managing catch not exceed than the quota allocated. Both of Australia and New Zealand have included over-catch action as an offence against law and regulation. This regulation is specified and associated with the main Fisheries Act. In their national law, there will be legal consequences against over-catch action.

Indonesia fisheries regulations have not included any provision regarding fish quota or fisheries under international arrangement. The range of fishing activities more tend to general fish stock. Majority of criminal provisions in the Fisheries Act are mentioned for any activity that involves harmful fishing equipment and any violation resulted from fishing license fraud. Moreover, the Indonesian Fisheries Act exempted small-scale fishers from the obligation to install Vessel Monitoring System (VMS). The monitoring system is questionable since the only legal control towards small-scale fishers is through their fishing license.

Since the VMS obligation is not applicable to small-scale fishers in Indonesia practices, as well as there is no clear definition on over-catch towards fish quota then it can be reckoned the monitoring action is low. Electronic monitoring is usually incorporated with at-sea inspection. Furthermore, the effectiveness of increasing penalties would be not optimal if there is no improvement in detection or inspection. ${ }^{23}$ If increasing detection is too costly with the vast water area of Indonesia, then the corrective action strategy towards non-compliance is possibly implemented through the size of the penalty to all parties engaged in fishing activities. There should be a list of categories about fishing vessels that always perform compliance, and the list of vessels that committed non-compliance. By doing so, incentive and corrective action will be properly implemented. To conclude, Indonesia national law and regulation must define the offence criteria of SBT over-catch to enable the corrective actions applies towards non-compliance.

${ }^{23}$ Oyanedel, R., Gelcich, S., \& Milner-Gulland, E. J. (2020). A synthesis of (non-) compliance theories with applications to small-scale fisheries research and practice. Fish and Fisheries, 21(6), 1120-1134. 
Relevant information has been obtained through a discussion with Government authority in semi-structure interview. It is known then, non-compliance with fishing quota during 2011 to 2014 was occurred due to the absence of sanction framework in CCSBT with regard to non-compliant member States with national quota allocated. Since CCSBT has released the Corrective Actions Policy, Indonesia has adopted the pay back scheme towards over-catch. The Government settles this pay back mechanism to CCSBT. Moreover, the fact that Indonesia's non-compliance has been came up for several fishing seasons and still occurs up to the current period demonstrates that the country does not have an effective legal framework to take action against fishing vessels that have contributed to over-quota. The necessary actions should cover either the over-catch by vessels of association member or the over-catch done by vessels out of the association membership itself. The study suggests for consideration on the criteria of offence in SBT fishing regulation, in particular to include the over-catch issue that catching SBT exceeds than the quota allocated is considered as an offence. Thus, reward and punishment will be applied to vessels which comply and the vessels which not comply. Early warning system might be employed to the associations and fishing companies in order to avoid over-catch. By doing so, the tuna association and the companies who joined membership will consider carefully towards every fishing vessel caught SBT.

\section{Conclusion}

International law instruments for conservation measures will never be worked unless the national laws of each member States support to do so. Without adequate law enforcement, the quota allocation system does not contribute to SBT sustainability. Non-compliance issue in SBT fishing by a member State has proved that CCSBT lacks enforcement capability to enforce their conservation measures when it comes to fishing practices at the national level of a country. On the other hands, the range of national legislations will determine whether the conservation objective is possible to be executed. This study has argued that the improvement of national law instruments should be focused on how to address the main cause of Indonesia's non-compliance in SBT quota allocation. While there is no such compliance strategy that fits a universal solution, the compliance law and regulations must be suitable for the nature and characteristic of the non-compliance being addressed. In the context of Indonesia, the engagement of small-scale fishers in SBT fishing is a typical condition in which the country has been dealing with over-catch problem.

First point of improvement is the need to link the small-scale fishermen to SBT fishery. It is suggested that in order to increase levels of compliance, it needs such greater legitimacy, thus, the greater involvement of fishers in the conservation process is essential. Second improvement is regarding compliance enforcement and corrective actions. The over-catch issue for some fishing seasons has shown the obligation to take necessary actions towards national vessels that violated the CCSBT provisions has not been implemented due to there is no effective sanction measures by tuna association against its fishermen who violated the quota allocation. The third improvement for 
Indonesia's law is to extend the extraterritorial jurisdiction beyond the national area which is high seas. Indonesia should use the right as a member of CCSBT to ensure compliance of conservation measures has always been achieved by other member states as well. Finally, the fourth improvement is concerning Indonesian legislation should be made to support a fisheries traceability. SBT caught by small-scale fisherman could potentially lead to illegal and unreported catch. This situation could impact to fisheries data uncertainties. It is important to identify and classify separately between the total catch from industry and small-scale fishers. Therefore, there is a need to establish a catch reporting mechanism for small-scale fishers.

\section{References}

Al Amaren, E. M., M. Z. bin M. Nor, and C. T. B. M. Ismail. (2020). Risks and Remedy in Islamic and Conventional Letter of Credit: Jordanian Practices," Int. J. Islam. Econ., vol. 2, no. 01, 54-63.

Bell, J. D., Leber, K. M., Blankenship, H. L., Loneragan, N. R., \& Masuda, R. (2008). A new era for restocking, stock enhancement and sea ranching of coastal fisheries resources. Reviews in fisheries science, 16(1-3), 1-9.

CCSBT. Corrective Actions Policy, Compliance Policy Guideline 3. (2018). Updated at the Twenty-Fifth Annual Meeting

Clark, E. A. (2011). Compliance enforcement in regional fisheries management organizations to which Australia is a party (Doctoral dissertation, University of Tasmania). 38.

Cogan, J. K. (2006). Noncompliance and the international rule of law. Yale J. Int'l L., 31, 189.

Commission for the Conservation of Southern Bluefin Tuna. (2013). Report of the Twentieth Annual Meeting of the Commission.

Commission for the Conservation of Southern Bluefin Tuna. (2019). Report of the Fourteenth Meeting of the Compliance Committee.

Cox, A. (2009). Quota allocation in international fisheries. OECD Food, Agric. Fish. Pap., no. 22 , pp. 1

Elise Anne Clark. (2011). "Compliance enforcement in regional fisheries management organizations to which Australia is a party." PhD diss., University of Tasmania, 38.

Hatcher, A., \& Pascoe, S. (2006). Non-compliance and fisheries policy formulation. In Developments in aquaculture and fisheries science (Vol. 36, pp. 355-373). Elsevier.

Interview with the Ministry of Fisheries and Marine Affairs of Indonesia in Jakarta on 3 February 2020

Jentoft, S. (2006). Beyond fisheries management: The Phronetic dimension. Marine Policy, 30(6), 671-680 
Khan, A. M., Mill, A. C., Gray, T. S., Jiang, M., Arief, H., Brown, A., ... \& Polunin, N. V. (2020). Reliability of the data on tuna catches obtained from the dockside in Indonesia: A study of stakeholders' perceptions. Marine Policy, 122, 104242.

Levontin, P., Kulmala, S., Haapasaari, P., \& Kuikka, S. (2011). Integration of biological, economic, and sociological knowledge by Bayesian belief networks: the interdisciplinary evaluation of potential management plans for Baltic salmon. ICES Journal of Marine Science, 68(3), 632-638.

Mclntyre, P. B., Reidy Liermann, C., Childress, E., Hamann, E. J., Hogan, J. D., Januchowski-Hartley, S. R., ... \& Pracheil, B. M. (2016). Conservation of migratory fishes in freshwater ecosystems (pp. 324-360). Cambridge University Press: Cambridge.

Miller, D. D., \& Sumaila, U. R. (2014). Flag use behavior and IUU activity within the international fishing fleet: Refining definitions and identifying areas of concern. Marine Policy, 44, 210.

Oyanedel, R., Gelcich, S., \& Milner-Gulland, E. J. (2020). A synthesis of (non-) compliance theories with applications to small-scale fisheries research and practice. Fish and Fisheries, 21(6), 1120-1134.

Polacheck, T. (2012). Assessment of IUU fishing for southern bluefin tuna. Marine Policy, 36(5), 1150-1165.

Rahmawati, Novia Tri. (2014). Pengelolaan Kuota Penangkapan Tuna Sirip Biru Selatan di Indonesia. Institut Pertanian Bogor. 50.

Southern Bluefin Tuna-Species Impact Statement. (2009). Available online from https://www.dpi.nsw.gov.au/ data/assets/pdf file/0004/508018/southern bluefi n tuna sis part 1.pdf

Tsamenyi, M., \& Hanich, Q. (2012). Fisheries jurisdiction under the Law of the Sea Convention: rights and obligations in maritime zones under the sovereignty of Coastal States. The International Journal of Marine and Coastal Law, 27(4),793.

Conflict of Interest Statement: The author(s) declares that the research was conducted in the absence of any commercial or financial relationships that could be construed as a potential conflict of interest.

Copyright: (C) 2021 HALREV. This is an open-access article distributed under the terms of the Creative Commons Attribution 4.0 International License (CC-BY 4.0), which permits unrestricted use, distribution, and reproduction in any medium, provided the original author and source are credited.

Hasanuddin Law Review (Hasanuddin Law Rev. - HALREV) is an open access and peer-reviewed journal published by Faculty of Law, Hasanuddin University, Indonesia. 